\title{
NOTES
}

\section{CRIMINAL LAW: VALIDITY OF INCONSISTENT VERDICTS}

$\mathrm{T}$

HE DILEMMA of inconsistent verdicts is aggravated by resort to inflexible rules. Nevertheless, most courts, seemingly unaware of the presence of divergent policy considerations, apply a single rule to all types of inconsistent verdicts. ${ }^{1}$ Thus, federal courts and some state courts uphold inconsistent verdicts in every case. In contrast, other state courts require that all convictions founded on the return of an inconsistent verdict be reversed.

The Supreme Court decision in United States v. Dunn ${ }^{2}$ established the federal rule that inconsistent verdicts will not be set aside. ${ }^{3}$ Federal

${ }^{1}$ If such policy factors have been considered by the courts, they have rarely been expressed in the decisions. For an obvious example of an inconsistent verdict see People v. Stovall, 94 Cal. App. 635, 27 I Pac. 576 (1928), where defendant was convicted on a count of grand theft for stealing an automobile but was acquitted upon a count charging the statutory offense of driving a vehicle without the owner's consent.

${ }_{284}$ U.S. 390 ( 1932 ). The defendant in Dunn was indicted for ( 1 ) maintaining a liquor nuisance, (2) illegal possession of liquor, and (3) illegal sale of liquor. The jury convicted defendant on the first count, but acquitted him on the other two. The Supreme Court upheld the conviction by determining that consistency in a verdict is not necessary. But see Justice Butler's strong dissent. 284 U.S. 390,394 (1932).

${ }^{3}$ Prior to the Dunn case in 1932 there was a split of authority in the circuit courts on the validity of an inconsistent verdict. In the Second, Fifth, Sixth, and Seventh Circuits, the rule was that the verdict of guilty on one count would stand, although inconsistent with a verdict of not guilty on another count. See Steckler v. United States, 7 F.2d 59 (2d Cir. 1925); Maceo v. United States, 46 F.2d 788 (5th Cir. 193I); Goszner v. United States, 9 F.2d 603 (6th Cir. 1925); Carrignan v. United States, 290 Fed. I 89 (7th Cir. 1923). In United States v. Bergdoll, 272 Fed. 498, 505 (E.D. Pa. I92I), the court remarked: "Among the admirable qualities of the human mind and character, consistency is singled out as a jewel. . . No one, however, is to be condemned for not possessing jewels, and he who has them is not expected to have them on view at all times. Mere formal logical consistency is not one of the crown jewels of juries, and happily so."

The Third Circuit, in its pre-Dumn decisions on inconsistent verdicts, held that a conviction based on an inconsistent verdict would not be upheld unless the verdict of guilty was supported by evidence other than that offered in support of the counts on which the defendant was acquitted. Speiller v. United States, 3I F.2d 682 (3d Cir. I 929); John Hohenadel Brewing Co. v. United States, 295 Fed. 489 (3d Cir. I924). However, there was a split of authority on the validity of an inconsistent verdict within the Eighth and Ninth Circuits. Compare Pankratz Lumber Co. v. United States, 50 F.2d I74 (9th Cir. 1931), Boyle v. United States, 22 F.2d 547 (8th Cir. I927) and Rosenthal v. United States, 276 Fed. 714 (gth Cir. 1921); with Peru v. United States, 
courts readily apply this rule for a simple disposition of the inconsistency issue, ${ }^{4}$ at times without determining whether an inconsistency in fact existed. ${ }^{5}$ Thus Dum has become an elixir for the perplexing problem of verdict inconsistency. ${ }^{6}$

State courts are widely split on the question of the validity of an inconsistent verdict. Some states, influenced by the reasoning in Dumm, have refused to reverse a conviction for inconsistency. ${ }^{7}$ Other jurisdic-

4 F.2d 881 (8th Cir. 1925), Bilboa v. United States, 287 Fed. 125 (9th Cir. 1923), and Boone v. United States, 257 Fed. 963 (8th Cir. 1919). Because of the split of authority in the Ninth Circuit before 1932, the court often displayed a tendency to determine that an apparently inconsistent verdict in reality was not necessarily inconsistent. See United States v. Anderson, 3I F.2d 436 (9th Cir. 1929); Hesse v. United States, 28 F.2d 770 (9th Cir. 1928); Lambert v. United States, 26 F.2d 773 (9th Cir. 1928); Baldini v. United States, 286 Fed. 133 (9th Cir. 1923).

For a short resume of the holdings in the circuit courts prior to Dutm see Annot," 80 A.L.R. I71 (1932).

'Most of the federal decisions on inconsistent verdicts since 1932 have adopted the rule established in Dumn to uphold a conviction on one count, when the defendant was acquitted on other counts-a situation similar to that presented in the Dimn case itself. Tri-Angle Club, Inc. v. United States, 265 F.2d 829 (8th Cir. 1959); United States v. Chiarella, 184 F.2d 903 (2d Cir. 1950); Catrino v. United States, 176 F.2d 884 (9th Cir. I949) ; Pilgreen v. United States, 157 F.2d 427 (8th Cir. 1946). However, a substantial number of decisions have broadly applied Dum to inconsistent verdicts of a different nature than that involved in the Dunn case. See United States v. Dotterweich, 320 U.S. 277 ( 1943); Apodaca v. United States, r88 F.2d 932 (roth Cir. 1951); United States v. General Motors Corp., 12 I F.2d 376 (7th Cir. 1941); Chiaravalloti v. United States, 60 F.2d 192 (7th Cir. 1932).

"See, e.g., United States v. National City Lines, Inc., 186 F.2d 562 (7th Cir. 1951); Robinson v. United States, 175 F.2d 4 (9th Cir. I949); Maugeri v. United States, 80 F.2d I99 (9th Cir. 1935). In Stein v. United States, 153 F.2d 737, 744 (9th Cir. 1946), the court stated: "We perceive no inconsistency in the verdicts, but even if there were, this court has uniformly ruled that inconsistency as to verdicts in plurality of counts in one indictment or information is not fatal."

"In only one known instance has a federal court indicated a disinclination toward adopting the broad propositions of Dimn. Manley v. United States, 238 F.2d 221 (6th Cir. 1956). In that case the court held that an inconsistency alone was not grounds for reversal, but when an obviously inconsistent verdict is returned, both the trial court and the reviewing court should be extraordiuarily careful in scrutinizing the record to ascertain any prejudicial error. The appellate court, upon discovery of such error in that case, reversed the trial court decision upholding the inconsistent verdict.

${ }^{7}$ Florida: Goodwin v. State, I 57 Fla. 751, 26 So. 2d 898 (1946) (citing Dunn). Indiana: Sichick v. State, 89 Ind. App. 132, 166 N.E. 14 (1929). Kansas: State v. Phillips, I36 Kan. 407, 15 P.2d 408 (1932) (citing Dunn); State v. Brundige, I 14 Kan. 849, 220 Pac. 1039 (1923). Montana: State v. Daly, 77 Mont. 387, 250 Pac. 976 (1926). Nebraska: Weinecke v. State, 34 Neb. 14, 51 N.W. 307 (1892). New Jersey: State v. Friedman, 98 N.J.L. 577, 1 20 Atl. 8 (1922). North Carolina: State v. Davis, 214 N.C. 787 , I S.E.2d 104 (1939). Ohio: Browning v. State, 120 Ohio St. 62,165 N.E. 566 (1929); Griffin v. State, 18 Ohio St. 438 (1868) (leading casc). 
tions, however, hold inconsistent verdicts void, relying upon the common law principle that no verdict will be upheld which creates a repugnancy or absurdity in a conviction. 8

The few courts that have reviewed an inconsistent verdict reached by a judge as the trier of fact have failed to distinguish this situation from the ordinary jury inconsistency, ${ }^{9}$ apparently relying on the doctrine that waiver of jury trial substitutes the judge for the jury in all respects. ${ }^{10}$ Although the defendant in Dunn was tried before a jury, application of the Dunn rule to judge-rendered inconsistent verdicts is somewhat justified by the broad language of that case. ${ }^{11}$ However, in a recent decision, United States v. Maybury, ${ }^{12}$ the Court of Appeals for the

Pennsylvania: Commonwealth v. Parrotto, 189 Pa. Super. 415, 150 A.2d 396 (1959) (citing Dumn); Commonwealth v. Watt, 187 Pa. Super. 51, 142 A.2d 423 (1958). South Dakota: State v. Sinnott, 72 S.D. 100, 30 N.W.2d 455 (1947) (citing Dumn). Wisconsin: Teske v. State, 256 Wis. 440, 4 I N.W.2d 642 (1950) (citing Dumn).

Prior to 1932 Colorado had adopted the rule that an inconsistent verdict required reversal, but in reliance on Dumn this jurisdiction promptly embraced the opposite view and upheld such verdicts. Compare Webb v. People, 83 Colo. I, 262 Pac. 906 (1927), with Crane v. People, 91 Colo. 2I, II P.2d 567 (1932), and Elstun v. People, 104 Colo. 302, 9I P.2d 487 (1939).

'In Commonwealth v. Haskins, 128 Mass. 60, 62 (1880), the court stated: "The record showed a verdict so inconsistent with itself, and so uncertain in law, that no judgment could be entered upon it." Arizona: State v. Fling, 69 Ariz. 94, 210 P.2d 22 I (1949). California: Ex parte Johnston, 3 Cal. App. 2d 32, 43 P.2d 54I (r 935); People v. Koehn, 207 Cal. App. 605, 279 Pac. 646 (1929). Georgia: Kuck v. State, I49 Ga. I91, 99 S.E. 622 (1919) (leading case). Illinois: Tobin v. People, 104 Ill. 565 (1882) (leading case). Washington: State v. O'Neil, 24 Wash.zd 802, I67 P.2d 47 (1946); State v. Tuerk, I65 Wash. 322, 5 P.2d 308 (1931). See also 2 Bishop, New Criminal Procedure $§$ IOI 5 (2d ed. Ig13).

'In McElheny v. United States, 146 F.2d 932 (9th Cir. 1944), the Dumn rule was applied to a trial before a judge without discussing whether the considerations were necessarily the same. Until the present case, McElheny was apparently the only federal decision involving an inconsistent verdict reached by a judge as trier of facts. For two state cases in which a judge returned an inconsistent verdict, see De Mott v. Notey, 4 Misc. 2d 996, 159 N.Y.S.2d roI (Nassau County Ct. 1956) (a misdemeanor tried before a police justice), and Jones v. State, 204 Md. 55, 102 A.2d 714 (1954). Neither court made a distinction between an inconsistent jury verdict and an inconsistent verdict in a case tried before a judge.

${ }^{20}$ Accord, United States v. Dudley, 260 F.2d 439 (2d Cir. 1958).

11 The Supreme Court in Dunn stated: "Consistency in the verdict is not necessary." 284 U.S. 390,393 (1932).

${ }^{19} 274$ F.2d 899 (2d Cir. 1960). The defendant in Maybury was indicted on two counts, for forgery of a check, and for uttering the same check knowing that it was forged. The only evidence offered by the government as to defendant's knowledge that the check had been forged was that the defendant himself had forged it. The trial judge, jury having been waived, acquitted the defendant on the forgery count but convicted him for uttering. On appeal, the defendant contended that the conviction 
Second Circuit, after a thorough analysis of the Dunn rule, ${ }^{13}$ held that policy considerations permitting jury inconsistencies were not applicable in a case tried to a judge and thus limited this rule to jury verdicts. ${ }^{14}$

on the uttering count should be set aside on the ground that it was inconsistent with an acquittal on the forgery count. The court upheld his contention, ruling that the conviction on the uttering count could not stand because of the inconsistency of an acquittal on the forgery count.

Judge Friendly was in favor of a new trial on both counts, but Judge Lumbard was of the opinion that the prohibitions of double jeopardy and collateral estoppel barred retrial on either count. Judge Hand, while doubting the appellate court's ability to determine from the record whether the trial judge's findings were inconsistent, voted with Judge Friendly to retry the defendant on the uttering count and with Judge Lumbard to bar a retrial on the forgery count. Thus, by compromise a majority of the court held that the defendant could be retried only on the uttering count.

Forgery and uttering an instrument knowing it to be forged are separate crimes. See Miller, Criminal LaW 414 (1934); Perkins, Criminal, Laaw, 307 (1957). Thus an acquittal on one count of an indictment charging both uttering and forgery would not usually be inconsistent with a conviction on the other count. See Pope v. State, 42 Ga. App. 680, 157 S.E. 211 (x93I); and State v. Hobl, 108 Kan. 26I, 194 Pac. 921 (1921) and State v. Donald, go Utah 533, 63 P.2d 246 (1936). However, where the only evidence of knowledge of the falsity of the forged instrument to support a conviction for uttering is derived from evidence that the defendant had forged the instrument himself, a conviction on the uttering count would necessarily be logically inconsistent with an acquittal on forgery. Conley v. United States, 257 F.2d 141 (6th Cir. 1958); State v. Lovell, 132 Kan. 759, 297 Pac. 685 (1931).

${ }^{18}$ The Maybury case is the first decision in which the Dunn rule has been thoroughly analyzed. By limiting the rule to jury verdicts, it is the first holding to place any restriction on the broad application of that rule. For an example of the perfunctory approach of the federal courts to inconsistent verdicts since the Dutnn decision, see Borum v. United States, 284 U.S. 596 (1932); United States v. Chiarella, 184 F.2d 903 (2d Cir. 1950); and Foshay v. United States, 68 F.2d 205 (8th Cir. 1933).

${ }^{14}$ If it is determined that an inconsistent verdict cannot stand, the difficult problem of whether the defendant should be retried arises. Before the Dunn case in 1932 a majority of the federal courts that considered this question held that res judicata precluded a conviction on one count after an acquittal on another, and dismissed the defendant. See Pankratz Lumber Co. v. United Startes, 50 F.2d 174 (gth Cir. 1931), and John Hohenadel Brewing Co. v. United States, 295 Fed. 489 (3d Cir. 1924). Contra, Rosenthal v. United States, 276 Fed. 714 (9th Cir. 1921) (inconsistent verdict reversed and case remanded for a new trial on both counts).

This question of retrial is entirely unsettled in the state courts. A number of states hold that an acquittal on one count is conclusive as to other counts, thus barring a conviction; the defendant is therefore dismissed. State v. Fling, 69 Ariz. 94, 210 P.2d 221 (1949); Ex parte Johnston, 3 Cal.2d 32, 43 P.2d 54 I (1935); Webb v. Pcople, 83 Colo. 1,262 Pac. 906 ( 1927 ). Other states hold that after reversal of an inconsistent verdict, defendant should be retried on all counts under which he had been originally indicted. State v. Akers, 278 Mo. 368, 213 S.W. 424 (1919); State v. O'Neil, 24 Wash. 2d 802, I67 P.2d 47 I (1946).

The unparalleled approach adopted in Maybury of retrying the defendant only on 
The reasons most frequently cited to explain inconsistent jury verdicts and to justify their being sustained are that they represent an attempt to mitigate punishment or a compromise by the jury in order to reach a unanimous decision. ${ }^{15}$ However, an inconsistent verdict reached by a judge is obviously not prompted by such considerations. By carefully examining the policy considerations behind the federal rule on inconsistent verdicts the court in the instant case logically limited the Dunn rule to jury verdicts.

Nevertheless, the court in Maybury seemingly overlooked a principle greatly relied upon in the Dunn decision, namely, that consistency

the count under which he had been convicted is a satisfactory solution to this problem. Thus, defendant is neither completely discharged nor does he risk retrial on all counts.

${ }^{15}$ Inconsistent verdicts have often been attributed to lemency on the part of the jury. Dunn v. United States, 284 U.S. 390 (1932); United States v. Cindrich, 241 F.2d 54 (3d Cir. 1957); and Boone v. United States, 257 Fed. 963 (8th Cir. 1919). In the leading decision supporting this proposition, Steckler v. United States, 7 F.2d 59, 60 (2d Cir. 1925), the court stated: "The most that can be said in such cases is that the verdict shows that either in the acquittal or the conviction the jury did not speak their real conclusions, but that does not show that they were not convinced of the defendant's guilt. We interpret the acquittal as no more than their assumption of a power which they had no right to exercise but to which they were disposed through lenity." The Supreme Court in Dunn relied heavily on the leniency argument asserted in Steckler.

Juries may hesitate to return verdicts of guilty on a large number of counts when the punishment that may be imposed on each count is severe. See Boone v. United States, 257 Fed. 963 (8th Cir. 1919). Although sentences usually run concurrently when a defendant is convicted on more than one count, fines and prison sentences have been accumulated from each conviction returned. See, e.g., United States v. Hare, I 53 F.2d 816 (7th Cir. 1946). The imposition of consecutive sentences lies within the discretion of the trial judge. Note, 45 HARv. L. REv. 535 (1932).

An inconsistent verdict may also be the product of a jury's compromise in order to reach a unanimous decision. If a majority of the jury is inclined to return a conviction on every count, but a few of the jurors are unwilling to convict on all counts, a compromise may result-conviction on some counts and acquittal on others. The strict criminal law requirement of unanimity is satisfied, although an inconsistent frerdict results. Accord, Andres v. United States, 333 U.S. 740 (r 948); Hibdon v. United States, 204 F.2d 834 (6th Cir. I953).

Only a few federal courts have imputed an inconsistent verdict to a mistake or misconception on the part of the jury. See Grant v. United States, 255 F.2d 34 I (6th Cir. 1958), and United States v. General Motors Corp., 121 F.2d $37^{6}$ (7th Cir. 1941).

The majority of state courts that uphold inconsistent verdicts have taken the detached attitude that the defendant is in no position to complain, since the jury returned a verdict more favorable than deserved on the evidence. See Sichick v. State, 89 Ind. App. 132, I66 N.E. I4 (1929); State v. Brundige, I I4 Kan. 849, 220 Pac. 1039 (1923); State v. Davis, 214 N.C. 787 , I S.E.2d 104 (1939). 
in verdicts is not required since each count acts as a separate indictment. ${ }^{16}$ This principle is equally applicable to cases tried before a judge. The separate indictment rule, however, is of questionable origin. Its source was a nineteenth century English decision that upheld a conviction on one count, even though the jury had failed to return its verdict on another count. ${ }^{17}$ Since that time the supposition that each count has the legal effect of a separate indictment has been asserted in practically every case sustaining convictions founded on inconsistent verdicts. ${ }^{18}$ Perhaps the Maybury decision reflects a conscious determination to disregard the multicount principle. The court based its decision squarely on seldom mentioned policies. This functional approach, it is submitted, is preferable to the a priori procedure of most courts that have adopted the multicount separate indictment principle.

While the judge-jury distinction drawn by the Maybury court prescribes a sound limitation on the federal rule on inconsistent verdicts, a further advance by the courts is suggested by the analytical approach adopted in this case. Distinctions should be drawn between the types of inconsistent verdicts. ${ }^{19}$ For example, the most common type of inconsistency is illustrated by Dunn, where a defendant charged with several related crimes was acquitted on some counts and convicted on

\footnotetext{
${ }^{10}$ As Judge Holmes explained in the Dunn case: "If separate indictments had been presented against the defendant for possession and for maintenance of a nuisance, and had been separately tried, the same evidence being offered in support of each, an acquittal on one could not be pleaded as res judicata of the other. Where the offenses are separately charged in the counts of a single indictment the same rule must hold." 284 U.S. 390,393 (1932). But see Sealfon v. United States, 322 U.S. 575 (1948), where the Supreme Court held that res judicata precluded a later conviction based on a separate indictment for the substantive crime, after the defendant had been acquitted under an indictment charging conspiracy to commit that crime.

${ }^{17}$ Latham v. The Queen, 5 B.\&S. 635, 122 Eng. Rep. 968 (Q.B. 1864).

${ }^{18}$ E.g., Carroll v. United States, 16 F.2d 951 (2d Cir. 1927); Gozner v. United States, 9 F.2d 603 (6th Cir. 1925); United States v. Malone, 9 Fed. 897 (C.C.S.D. N.Y. 1881); Williams v. State, 204 Md. 55, 102 A.2d 714 (1954); Browning v. State, 120 Ohio St. 62, 165 N.E. 566 (1929); Griffin v. State, 18 Ohio St. 438 (1868); Commonwealth v. Watt, $187 \mathrm{~Pa}$. Super 5I, 142 A.2d 423 (1958).

${ }^{19}$ While courts have failed to distinguish the different types of inconsistent verdicts, scholars in the field of criminal procedure have not only failed to make such distinctions, but have neglected the whole subject of "inconsistent verdicts." See 5 WHARTON, Criminal Law and Procedure $\$ 2128$ (12th ed. 1957), where the problem of verdict consistency is considered in three short paragraphs, and Orfield, Criminal ProCEDURE FROM ARREST TO APPEAL 483 (1947), where three somewhat longer paragraphs are devoted to inconsistent verdicts. Another leading authority on criminal procedure, Moreland, Modern Criminal Procedure (1959), fails even to consider inconsistent verdicts.
} 
others on evidence that logically would require conviction or acquittal on all. ${ }^{20}$ Such an inconsistent verdict may well be imputed to the underlying considerations of leniency or compromise by the jury. ${ }^{21}$ In contrast, where a single defendant is convicted of both larceny and receiving stolen property, crimes which by their nature cannot be committed by the same person, ${ }^{22}$ the verdict is not a result of jury leniency or compromise. Therefore, because the policy considerations appropriate to one type of inconsistent verdict may not be applicable to another type of inconsistency, ${ }^{23}$ courts should not indiscriminately apply a general rule of validity or fatality to every inconsistent verdict.

${ }^{30}$ This type of inconsistency was prevelant during prohibition, when it was common to indict a defendant on three counts: (1) selling liquor, (2) possessing liquor, and (3) maintaining a common nuisance. The inconsistency resulted when the defendant was convicted on some counts and acquitted on others on evidence sufficient to uphold a conviction on all three counts. See Stockman v. United States, 8 F.2d $2 \times$ I (gth Cir. 1925); Marshallo v. United States, 298 Fed. 74 (2d Cir. 1924); John Hohenadel Brewing Co. v. United States, 295 Fed. 489 (3d Cir. 1924); Carrignan v. United States, 290 Fed. 189 (7th Cir. x923); Bilboa v. United States, 287 Fed. $\times 25$ (9th Cir. 1923); Baldini v. United States, 286 Fed. 133 (9th Cir. x923). However, there are many other situations in which an acquittal on one or more counts would be inconsistent with a conviction on other counts. For example, in United States v. Chiarella, 184 F.2d 903 (2d Cir. 1950), a general indictment for counterfeiting charged four counts: (1) receiving, (2) possessing, (3) selling, and (4) conspiracy. Defendant was found guilty by the jury only on the second count. In Catrino v. United States, 176 F.2d 884 (9th Cir. 1949), defendant was prosecuted under two counts: ( 1 ) subornation of perjury and (2) obstruction of justice. He was convicted on the second count, but acquitted on the first. See case cited note 1 suppra, and forgery and uttering cases cited note I supra.

${ }^{21}$ See note $x_{4}$ supra.

${ }^{29}$ This type of inconsistent verdict is manifestly different from that found in Dunn. The underlying policy consideration of leniency and compromise have no merit in this situation, since a jury is hardly lenient when it convicts the defendant of both crimes, and certainly there is no compromise, since a unanimous verdict was returned on both counts. While no court has upheld an inconsistency resulting from conviction on two counts charging separate crimes that by their nature cannot be committed by the same person, such an inconsistent verdict has in certain jurisdictions become the basis of a general rule requiring reversal for all inconsistent verdicts. See Tobin v. People, xo4 I1l. 565 ( 1882 ) (conviction on counts of larceny and receiving); Commonwealth v. Haskins, 128 Mass. 60 ( 1879 ) (also larceny and receiving). The two preceding cases established the rule in their respective jurisdictions, that an inconsistent verdict cannot stand. For other decisions holding that a conviction rendered on counts charging crimes which by their nature cannot be committed by the same person, see Davis v. United States, 37 App. D.C. 126 ( $191 x$ ) (one count charging false pretenses, another charging embezzlement, defendant convicted of both crimes); State v. Friedman, 98 N.J.L. 577, 120 Atl. 8 (1922) (larceny and receiving); The Queen v. Evans, 7 Cox C.C. $x_{5} x$ (1856) (stealing and receiving).

${ }^{28}$ Several other types of inconsistent verdicts should be distinguished. An incon- 
Several courts have followed a sounder course of examining the type of inconsistency involved in each case. ${ }^{24}$ For example, in one case a defendant was indicted on two counts, each charging substantially the same crime. The court held that the conviction on one count could not stand beside acquittal on the other. ${ }^{25}$ In a later case the same court

sistent verdict has frequently been returned in cases in which a corporation and its officers have been jointly indicted for the same crime; on the same evidence the corporate defendant is convicted while the individual defendants are acquitted. See Magnolia Motor \& Logging Co. v. United States, 264 F.2d 950 (9th Cir. 1959); Southern Advance Bag \& Paper Co. v. United States, 133 F.2d 449 (5th Cir. 1943) ; American Medical Ass'n v. United States, 130 F.2d 233 (D.C. Cir. 1942); Pankratz Lumber Co. v. United States, 50 F.2d 174 (9th Cir. 1931). Such inconsistency can be attributed to leniency by the jury. Compare United States v. Dotterweich, 320 U.S. 277 (1943), where the corporation president was convicted and the corporate defendant was acquitted. The court imputed such an inconsistency to carelessness, compromise, or a belief that the responsible individual should suffer the penalty instead of merely increasing the cost of running the business.

Another distinct type of inconsistency results when some co-defendants are acquitted and others convicted on evidence equally strong against all. See Apodaca v. United States; 188 F.2d 932 (roth Cir. 1951); Chiaravalloti v. United States, 60 F.2d 192 (7th Cir. 1932); Nadl v. United States, 6 F.2d 574 (7th Cir. 1925); United States v. Bergdoll, 272 Fed. 498 (E.D. Pa. 1921). While this form of inconsistency may possibly be attributed to jury leniency, such a power on the part of the jury should not be sanctioned by the courts in this situation. The jury can either believe or disbelieve the testimony of a witness, but the jury should not have the power to believe the testimony of a witness as to one defendant, and to discredit the testimony of the same witness as to a co-defendant.

Still another type of inconsistent verdict results when a defendant is indicted under counts charging substantially the same crime, and a conviction is returned on each count. $E . g .$, Griffin v. State, 18 Ohio St. 438 (1868) (conviction returned on each of several counts charging the same murder but on different days). See Fulton v. United States, 45 App. D.C. 27 (1916) (defendant charged on one count of embezzlement from $A$, and in another count with embezzlement of the same money from B, C, D, and E; jury returned a conviction on both counts). This type of inconsistency would seem to arise from a misconception or inistake by the jury, not from jury leniency or compromise.

As can readily be seen, policy considerations will vary depending on the type of inconsistency. Courts have not only failed to consider the reasons behind a particular inconsistent verdict but have also failed to distinguish one type of inconsistency from another. Because of this failure to draw such distinctions an all-encompassing rule has been applied to this variety of inconsistencies, often resulting in injustice to a particular defendant.

${ }^{24}$ Compare Heinze v. State, 184 Md. 613, 42 A.2d 128 (1945), with Williams v. State, 204 Md. 55, 102 A.2d 714 (1954) and Leet v. State, 203 Md. 285, 100 A.2d 789 (1953). In the Leet case the court stated: "While it is true that a finding of guilt on two inconsistent counts will be declared invalid in Maryland ... it does not follow that a conviction on one count may not stand because of an inconsistent acquittal on another count." Id. at 293, 100 A.2d at 793.

${ }^{25}$ State v. Akers, 278 Mo. 368,213 S.W. 424 (1919). 
held that a conviction for possessing liquor and an acquittal for transporting it, although inconsistent, did not constitute grounds for reversal. $^{26}$ Most courts, however, have failed to distinguish the diverse types of inconsistencies. $2 \pi$

The Maybury decision has introduced an intelligent approach into this neglected and confused area of the law. It may well establish a definite trend away from a blind following of the Dumn rule, not so much because of its narrow holding, but because of its careful analysis of the law of "inconsistent verdicts."

\footnotetext{
${ }^{20}$ State v. Ridge, 275 S.W. 59 (Mo. App. 1925).

${ }^{27}$ If such distinctions were made, and cases decided accordingly, any resulting conflict among the various jurisdictions as to the validity of a particular type of inconsistency would be attributable to diverse policy considerations of the desirability of requiring an impeccable verdict in a specific situation.
} 